\title{
How Lebanese Channels Intervene Subjectively in Displaying Demagoguery and Violent Rhetoric
}

\author{
Fawziya K. Tarhini ${ }^{1,2, *}$, Rabih Nabhan ${ }^{1}$ \\ ${ }^{1}$ Faculty of Arts and Sciences, Holy Spirit University of Kaslik, Lebanon \\ ${ }^{2}$ School of Education, Lebanese International University, Lebanon \\ * Corresponding author: fawziah.k.tarhini@ net.usek.edu.lb
}

\begin{abstract}
Lately, in the Lebanese context, several events have emerged among media channels that are, currently and diligently, working to incite competition, manufacture news, and highly attract audience's attention so to change their perspectives in a way to serve the channels' stakeholders own hidden agendas. Having said that, Lebanese media channels tend to choose certain events and narrate them in a way to fulfil their purpose. These ways include pragmatic mechanisms to determine what is newsworthy and what is not. This paper aims at investigating, using the Bednark and Caple's (2012) model, how Lebanese medial channels intervene, subjectively, in displaying aggressive rhetoric during their information bulletin introduction.
\end{abstract}

Keywords: Pragmatics, presupposition, modality, deixis, newsworthiness, rhetoric, demagoguery, bullying, violent speech 


\section{INTRODUCTION}

In a country that is so diverse and that carries a wide array of opinions and orientations, it is only normal that reporters and TV channels manufacture the importance of certain events to influence and attract the audience's attention. Lebanese TV channels usually rely on language pragmatics mechanisms to surpass the barriers of thoughts. Hence, this study aims at (1) identifying the pragmatic mechanisms in the news information bulletin introductions, (2) identifying the worthiest news values, and (3) setting a framework to analyze how these channels are displaying aggressive rhetoric and political violence from a language science perspective. This paper hypothesizes that: 1) Lebanese TV channels rely heavily on pragmatic mechanisms to affect and influence their audience, 2) the significance of news values differs from one channel to another, 3) Lebanese channels rely heavily on presuppositions, and 4) modality and deixis are also used considerably to relay messages to the audience.

\section{LITERATURE REVIEW}

\section{A. News}

In 2002, Reah defined news as providing information about a certain event that is happening and is of interest to a certain audience, and since it targets a large group of people, it is referred to as mass media.

\section{B. News Discourse}

Discourse is basically a way to constitute knowledge and to limit the way we talk about things (Fowler, 2013). It is also believed that the main function of discourse is to control people's minds (Al-Duleimi \& Al-Ebadi, 2016). In 2017, Ah Hindawi and Al Ebadi expressed that news discourse is a reflection of values rather than being value free, and that language is the best mean of expression.

\section{Newsworthiness}

In order to identify newsworthiness or intervening subjectively, one needs to look at news values; they are elements that place value on one event rather than the other (Van Dijk, 1991). In this study, the Bednarek and Caple's (2012) model of newsworthiness is adopted; it includes negativity, impact, timeliness, and proximity.

Negativity: this value is related to the existence of disasters, wars, damage, and so on. This type of events makes the news worthy (Conboy, 2002).

Impact: events that have a greater influence on the audience are considered more newsworthy (Van Dijk, 1991).

Timeliness: events that take place recently are considered more newsworthy (Bell, 1991) in addition to the ongoing events and the ones that will happen in the near future (Bednarek \& Caple, 2012). 
Proximity: an event is worthier if it is local rather than distant ones that are delivered cognitively (Bednarek \& Caple, 2012).

\section{Pragmatic Mechanisms}

\section{A. Presuppositions}

Al Hinadwi and Al Ebaid stated in 2017 that presuppositions are defined as the implicit meaning taken for granted, and which remains constant even under negation. We have different types of presuppositions which will be listed below.

\section{a. Existential Presuppositions}

According to Fairclough (1995, pp.6), existential presupposition indicates the existence of a certain entity or thing. For example, "The kind of France is bald." It presupposes the existence of a king to France who is bald (Polyzou, 2015).

\section{b. Factive Presupposition}

In the example "Alice regrets that it is raining", the predicate in which the reading of the object is in reference to, the terminology is retained as a condition on the speaker's belief; in other words, the predicate makes the utterance of the entire sentence anomalous in case the speaker's belief does not include the preposition expressed by the complement of the factive predicate (Katz \& Langendoen, 1976). Going back to point one, the verb "regrets" presupposes that Alice believes it is raining.

\section{c. Lexical Presupposition}

In lexical presupposition, "the use of one form with its asserted meaning is conventionally interpreted with the presupposition that another un-asserted meaning is understood" (Yule, 1996). In Lexical presupposition, the speaker uses a particular expression which presupposes another concept, but in Factive presupposition, the speaker uses a particular expression to presuppose the truth of the information that is stated later (AlHindawi \& Al-Ebadi, 2017). In the example "you are late again" presuppose that "you were late before".

\section{d. Structural Presupposition}

In structural presupposition, there is an assumption that part of the structure contains information considered as known (Yule, 1996). In the example, "When did he leave?" the presupposition that the information after the WH form is already known (Al-Hindawi \& AlEbadi, 2017). 


\section{e. Non-factive Presupposition}

According to Yule (1996), a non-factive presupposition is one that is considered untrue. The verbs included are similar to: dream, imagine, pretend, etc... In the example "I dreamt that I was rich" the non-factive presupposition is that I was not rich.

\section{f. Counter-factive Presupposition}

In this type, there is the assumption that certain information is opposite to the truth (Yule, 1996). This can be expressed through the use of conditional sentences; for example, in the sentence "If Hannibal had only had twelve more elephants, the Romance languages would not his day exist." The presupposition is that Hannibal did not have twelve more elephants (Al-Hindawi \& Al-Ebadi, 2017).

\section{E. Modality}

In order to understand modality, which is another area of grammar, one needs to take into consideration the interpersonal features of its contexts of use (Thornbury \& Slade, 2006). Modality mainly deals with the way speakers express their attitudes or judgments in regard to the current content; it is signaled by the use of modal verbs (must, may, will, could, etc...) and the so-called semi modals (have to, supposed to, be going to, etc...).

There are two types of modality: deontic and epistemic (Givón, 1993). Epistemic modality is of lower certainty or probability, and, on the other hand, deontic modality is of various senses of ability, intent, preference, obligation, necessity or permission (Al-Hindawi \& Al-Ebadi, 2017).

\section{F. Deixis}

Deixis derives from the Greek term for "finger" and is used to indicate that the speaker is pointing with his/her finger (Thornbury \& Slade, 2006). There are three types of Deixis indicated as follows.

a. Personal: it covers the speaker, hearer, and over-hearers. Certain expressions are used such as: this, that, these, I, we, he, she, you, him, etc... (Levinson, 1983).

b. Spatial: It refers to the immediate space (here, there) (Thornbury \& Slade, 2006).

c. Temporal: It refers to time (now, then, in, at, etc...) (Thornbury \& Slade, 2006). 


\section{G. Demagoguery}

According to Lomas (1961), demagoguery is described as "the process whereby skilled speakers and writers seek to influence public opinion by employing the traditional tools of rhetoric with complete indifference to truth." Demagogues employ the most effective communication technologies to carry on with their propaganda (Nacos, Shapiro, \& BlochElkon, 2020).

\section{H. Violent Speech}

Violent speech can include physical or non-physical violence. It can also cause physical damage, a personal moral damage, or collective moral damages, and it includes the categories of violent incitement, personal offence, discrimination incitement, and collective offence (Miro-Llinares \& Rodriguez-Sala, 2016).

\section{METHODOLOGY}

The analysis part will reply basically on the two levels discussed previously: newsworthiness, and pragmatic mechanisms. By the means of pragmatic mechanisms, news values are created. As such, news values will lead to newsworthiness and eventually cast an impact on the audience.

Newsworthiness: The newsworthiness value will be analyzed to see whether or not it has been initiated by one or more of the pragmatic mechanisms. The frequency of news values will also be calculated in the information bulletin introductions of the different channels and will display

Pragmatic mechanisms: The use and the frequency of pragmatic mechanism will be studied in the different information bulletin introductions of the news channels. 


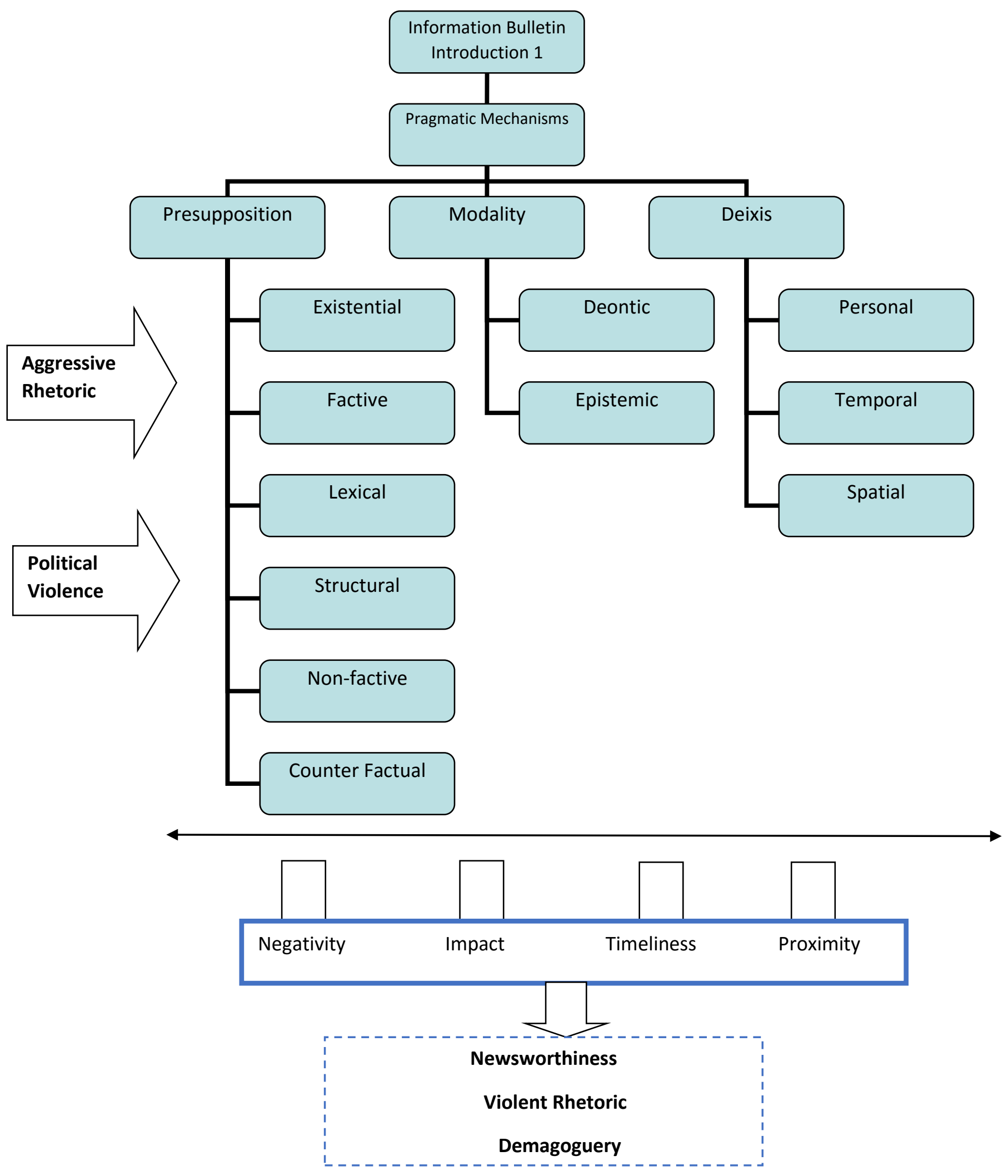




\section{RESULTS}

Based on the previous model, an analysis of the results of both the pragmatic mechanisms and newsworthiness will take place.

According to Conboy (2002), "negativity" is newsworthy since it talks about disasters, wars, and events that can conflict harm on people. This has been highly demonstrated through the use of presupposition in all the seven information bulletin introductions of Lebanese Channels.

As for "Impact", according to Van Dijik (1991), events that have a greater influence on the audience are considered more newsworthy, and hence, this has been demonstrated in the seventh information bulleting introductions of Lebanese channels through the use of presuppositions and modality.

As for "timeliness", according to Bell (1991), events that took place recently are considered more newsworthy than those who took place ahead of time. Hence, Lebanese channels relied heavily on this news value through the use of the pragmatic mechanism "deixis".

In regard to "proximity", events which are local are considered more newsworthy than those which are not (Bednarek \& Caple, 2012). This was also highly demonstrated in all the seven information bulletin introductions.

Below are the tables demonstrating the frequencies of each news value and pragmatic mechanisms.

Table 1 Frequency of News values in Information Bulletin Introductions

\begin{tabular}{|l|l|l|l|l|}
\hline Information Bulletin Introduction & News values & & & \\
\hline & Negativity & Impact & Timeliness & Proximity \\
\hline Info Bulletin Intro 1 & $\% 60$ & $\% 10$ & $\% 10$ & $\% 10$ \\
\hline Info Bulletin Intro 2 & $\% 33.333$ & $\% 25$ & $\% 33.333$ & $\% 8.333$ \\
\hline Info Bulletin Intro 3 & $\% 8.33$ & $\% 66.66$ & $\% 22.22$ & $\% 0$ \\
\hline Info Bulletin Intro 4 & $\% 33.333$ & $\% 41.666$ & $\% 16.666$ & $\% 8.333$ \\
\hline Info Bulletin Intro 5 & $\% 33.33$ & $\% 44.444$ & $\% 11.111$ & $\% 11.111$ \\
\hline Info Bulletin Intro 6 & $\% 55.555$ & $\% 33.333$ & $\% 0$ & $\% 11.111$ \\
\hline Info Bulletin Intro 7 & $\% 42.88$ & $\% 42.8$ & $\% 7.1$ & $\% 7.1$ \\
\hline
\end{tabular}


Table 2 Frequency of Pragmatic Mechanisms

\begin{tabular}{|l|l|l|l|}
\hline $\begin{array}{l}\text { Information } \\
\text { Bulletin } \\
\text { Introduction \# }\end{array}$ & \multicolumn{3}{|l|}{ Frequency of Pragmatic Mechanisms } \\
\hline & Presuppositions & Modality & Deixis \\
\hline 1 & $\% 56.25$ & $\% 25$ & $\% 18.75$ \\
\hline 2 & $\% 60$ & $\% 16$ & $\% 24$ \\
\hline 3 & $\% 60$ & $\% 11$ & $\% 30$ \\
\hline 4 & $\% 51$ & $\% 27.5$ & $\% 21.5$ \\
\hline 5 & $\% 58$ & $\% 15.7$ & $\% 26.3$ \\
\hline 6 & $\% 55.88$ & $\% 20.5$ & $\% 23.5$ \\
\hline 7 & $\% 58.9$ & $\% 17.9$ & $\% 23$ \\
\hline
\end{tabular}

Table 3 Detailed Pragmatic Mechanisms Frequency in IBIs

\begin{tabular}{|c|c|c|c|c|c|c|c|}
\hline IBI & $\begin{array}{l}\text { Info } \\
\text { Intro } 1\end{array}$ & IBI2 & IBI3 & IBI4 & IBI5 & IBI6 & IBI7 \\
\hline $\begin{array}{l}\text { Existential } \\
\text { Presupposition }\end{array}$ & $\% 3$ & $\% 20$ & $\% 3$ & $\% 6$ & $\% 15$ & $\% 9$ & $\% 12$ \\
\hline Factive Presupposition & $\% 16$ & $\% 4$ & $\% 30$ & $\% 15$ & $\% 10$ & $\% 14$ & $\% 15$ \\
\hline Lexical Presupposition & $\% 6$ & $\% 16$ & $\% 0$ & $\% 6$ & $\% 10$ & $\% 6$ & $\% 2$ \\
\hline $\begin{array}{l}\text { Structural } \\
\text { Presupposition }\end{array}$ & $\% 23$ & $\% 8$ & $\% 15$ & $\% 20$ & $\% 21$ & $\% 29$ & $\% 18$ \\
\hline $\begin{array}{l}\text { Non-factive } \\
\text { Presupposition }\end{array}$ & $\% 0$ & $\% 0$ & $\% 3$ & $\% 0$ & $\% 0$ & $\% 0$ & $\% 2$ \\
\hline $\begin{array}{l}\text { Counter-factual } \\
\text { Presupposition }\end{array}$ & $\% 6$ & $\% 12$ & $\% 3$ & $\% 3$ & $\% 0$ & $\% 0$ & $\% 7$ \\
\hline Deontic Modality & $\% 0$ & $\% 0$ & $\% 0$ & $\% 0$ & $\% 0$ & $\% 3$ & $\% 0$ \\
\hline Epistemic Modality & $\% 20$ & $\% 16$ & $\% 11$ & $\% 26$ & $\% 15$ & $\% 17$ & $\% 18$ \\
\hline Personal Deixis & $\% 13$ & $\% 20$ & $\% 26$ & $\% 12$ & $\% 0$ & $\% 6$ & $\% 12$ \\
\hline Spatial Deixis & $\% 6$ & $\% 4$ & $\% 0$ & $\% 3$ & $\% 15$ & $\% 11$ & $\% 12$ \\
\hline Temporal Deixis & $\% 6$ & $\% 0$ & $\% 7$ & $\% 9$ & $\% 10$ & $\% 5$ & $\% 2$ \\
\hline Total & $\sim \% 100$ & $\% 100$ & $\sim \% 100$ & $\% 100$ & $\sim \% 100$ & $\% 100$ & $\% 100$ \\
\hline
\end{tabular}




\section{A. News Values}

In table one, it is noticed that the different channels relied on demonstrating different news values in their introductions even though some of them are common. We can see the introduction $1,2,6, \& 7$ demonstrated mainly negativity while introductions $3,4, \& 5$ demonstrated the impact value of newsworthiness.

\section{B. Pragmatic Mechanisms Usage}

As it can be seen in the above tables, there are three main pragmatic mechanisms used in the seven information bulletin introductions of Lebanese Channels. As it is shown in table 2 , the presupposition mechanism received the highest percentage of usage in the seven IBIs while modality and deixis were used approximately in an equal manner.

In considering table 3 , the different channels relied on different pragmatic mechanisms to relay their messages to the audience. Information Bulleting Introduction 1 relied basically on structural presupposition and epistemic modality with percentages of $\% 23$ and \% 20 respectively. In Information Bulletin Introduction 2, the Lebanese channel used mainly existential presupposition and personal deixis with a percentage of 20 . In Information Bulletin Introduction 3, the Lebanese channel relied more factive presupposition with a percentage of 30 and secondly relied on the use of personal deixis with a percentage of 26 . As for Introduction Bulletin Information 4, the channel relied basically on epistemic modality (\%26) and secondly relied on structural presupposition (\%20) to relay its messages to the audience. In Information Bulletin Introduction 5, the channel relied on structural presupposition (\%21), existential presupposition (\%15), and spatial deixis (\%15). In Information Bulletin Introduction 6, the channel relied heavily on structural presupposition (\%29) and epistemic modality (\%17). As for Information Bulletin Introduction 7, the channel relied on structural presupposition and epistemic modality with a percentage of 18 .

It is also obvious in table three that most channels relied on structural presupposition and epistemic modality in their strategy to communicate with the Lebanese. Deontic modality was rarely used with $\% 0$ for most introductions.

\section{DISCUSSION}

\section{A. Presupposition, Newsworthiness, Demagoguery}

One form of an aggressive behavior is demagoguery (Lissborg, 2018). Demagoguery is basically a process in which a skilled speaker or a writer intends to influence public opinion by using traditional tools of rhetoric with complete indifference to truths (Lomas, 
1961). This is basically the main thing that the Lebanese channels are trying to do as a part of their propaganda. The main tool that is used in this process is presupposition which was demonstrated in the high percentages in the Information Bulletin Introductions;

presuppositions were used to endorse the value of negativity, which will surely be considered newsworthy to most Lebanese, and hence demagoguery was practiced upon the audience. For example, in Information Bulletin Introduction 1, the channel was trying to direct the audience against a group of deputies by using structural presupposition and foreshadowing that this might cause a tremendous negative effect on Lebanon. This is shown through this extract "The deputies who relieved themselves and Riad Salameh from the responsibility of making such a decision". This is interpreted with the presupposition that it is already known that those deputies relieved themselves and Riad Salameh from the responsibility which has a negative impact on the Lebanese people. Another example is manifested in Information Bulletin Introduction 2, when the channel used lexical presupposition in saying "She also explained that" meaning that this piece of information was mentioned before. In this piece of information, the ambassador was talking about pulling the diplomats' families out of the country due to the bad circumstances Lebanon is passing through. The ambassador assured that its country will continue to support Lebanon but, at the same time, pulled out all its diplomats from the country. The channel used this information to demonstrate the value of impact on the Lebanese and arise in them the fear of the future; that is one form of demagoguery.

Another form of an aggressive behavior is bullying; and usually with influential parties which engage in demagoguery and assail political opponents, the consequences transcend the hate speech on social media platforms (Nacos et al., 2020). So bullying that is executed through linguistic violence and through powerful parties is dangerous and is based on supremacy and predominance (Apressyan, 1998). Presupposition was used as an important device in executing bullying. For example, in Information Bulletin Introduction 4, the channel used structural presupposition to indicate that the bad infrastructure in Lebanon is a reflection of the bad politicians who were responsible for building it as shown in this quote "even the snow could not hide the bad infrastructure which is quite similar to the bad selves of the politicians responsible for building it." Here, the channel was highlighting the news value of negativity and bullying verbally the politicians of a certain party by using structural presupposition.

\section{B. Modality, Newsworthiness, Violent Rhetoric}

According to Miller (2005), as part of propaganda, communication is used either as transmission of information (disseminating information farther and faster), as a ritual (a sacred ceremony that draws people together in fellowship and communities), or as a ritual of excommunication that pit groups against each other. Now going back to point one and the use of a linguistic toolbox, the analysis showed that his pragmatic mechanism has been used to 
maximize the news values of negativity and impact through displaying violent rhetoric. For example, in Information Bulletin Introduction 7, the channel was attacking the Lebanese president by maximizing the newsworthiness of the impact of the president caring only about himself and accusing the president of abusing his judicial powers to support his son in law by

using epistemic modality (will); this was manifested in saying "then we will reveal all the skeletons in your closets". Another examples can be seen in Information Bulletin Introduction 1, the channel used adjectives and nouns as bombs dropped on their audience such as (missing brave souls, the republic of hysteria, its citizens are doomed and its politicians are abusers); and then, the channel used epistemic modality to maximize the news value of negativity by saying that "the whole system will collapse".

\section{Deixis, Newsworthiness, Violent Rhetoric}

In regard to Deixis, it is mainly used - as the two previous pragmatic mechanisms - to maximize negativity and timeliness through displaying violent rhetoric. For more illustration, in information Bulletin Introduction 1, and since events that happen recently are considered more newsworthy than old ones, the channel focused on a next week's hearing which will have an impact on the Lebanese. Another example would be Information Bulletin Introduction 3 in which the channel used personal deixis to refer to the careless of the Lebanese displaying a violent rhetoric against them by accusing them that they don't take things seriously; as if this is an indirect way to push the Lebanese to act and revolt.

\section{CONCLUSION}

Based on the previously mentioned analysis and discussion, the below conclusions were made.

1) Lebanese channels utilize pragmatic mechanisms to maximize newsworthiness.

2) Lebanese channels employ demagoguery and violent speech in the Information Bulletin Introductions.

3) Lebanese channels used presupposition the most in the IBI to relay specific messages.

4) Lebanese channels also used modality and deixis in the IBL to relay specific messages.

5) Certain presuppositions, modality, and deixis types were not used.

6) Negativity and impact were the most newsworthy. 


\section{References}

Al-Duleimi, A., \& Al-Ebadi, H. (2016). Ideology in news reports: Al-jazeera reporters as representative: A critical discourse analysis. British Journal of English Linguistics, 4(2), 53-66.

Al-Hindawi, F. H., \& Al-Ebadi, H. K. (2017). Pragmatics of political news reports worthiness. International Journal of English Linguistics, 7(4), 113-127.

Apressyan, R. G. (1998). Violent speech. Peace Review, 10(4), 587-591.

Bednarek, M., \& Caple, H. (2012). News discourse A\&C Black.

Bell, A. (1991). The language of news media Blackwell Oxford.

Conboy, M. (2002). The press and popular culture Sage.

Fairclough, N. (1995). Critical discourse analysis/fairclough N. London: Lohgman,

Fowler, R. (2013). Language in the news: Discourse and ideology in the press Routledge.

Givón, T. (1993). English grammar: A function-based introduction John Benjamins Publishing.

Griffiths, P. (2006). Introduction to english semantics and pragmatics Edinburgh university press.

Katz, J. J., \& Langendoen, T. (1976). Pragmatics and presupposition. Language, 52(1), 1-17. doi:10.2307/413205

Levinson, S. (1983). Pragmatics Cambridge University Press.

Lissborg, A. (2018). Demokrati och demagogi: En studie om demagogisk retorik.

Lomas, C. W. (1961). The rhetoric of demagoguery. Western Speech, 25(3), 160-168.

Miro-Llinares, F., \& Rodriguez-Sala, J. J. (2016). Cyber hate speech on twitter: Analyzing disruptive events from social media to build a violent communication and hate speech taxonomy. International Journal of Design \& Nature and Ecodynamics, 11(3), 406-415.

Nacos, B. L., Shapiro, R. Y., \& Bloch-Elkon, Y. (2020). Donald trump: Aggressive rhetoric and political violence. Perspectives on Terrorism, 14(5) 
Polyzou, A. (2015). Presupposition in discourse: Theoretical and methodological issues. Critical Discourse Studies, 12(2), 123-138.

Reah, D. (2002). The language of newspapers Psychology Press.

Thornbury, S., \& Slade, D. (2006). Conversation: From description to pedagogy Cambridge University Press.

Van Dijk, T. (1991). The interdisciplinary study of news as discourse, u: Jensen, K. B. and jankowski, NW (ur.) A handbook of qualitative methodologies for mass communication research.

Yule, G. (1996). Pragmatics. Oxford: Oxford University Press.

Table 4 Appendix A Presupposition (Information Bulletin Introduction 1)

\begin{tabular}{|c|c|c|}
\hline \# & Text & Presupposition Type \\
\hline 1 & $\begin{array}{l}\text { The deputies who relieved themselves and Riad Salameh from the } \\
\text { responsibility of making such a decision }\end{array}$ & Structural \\
\hline 2 & Why would the government set such a plan? & Structural \\
\hline 2 & Why would the government set such a plan? & Lexical \\
\hline 3 & Who will fund this plan? The ministry of finance or the Bank of Lebanon & Structural \\
\hline 4 & As long as there is no clear answer to this point & Factive \\
\hline 5 & The same will apply to next week's hearing & Factive \\
\hline 6 & When the council will flee his responsibilities & Structural \\
\hline 7 & Where the Lebanese money is being abused day by day & Structural \\
\hline 8 & $\begin{array}{l}\text { After the Lebanese people have been robbed, it was time to make them } \\
\text { face hunger. }\end{array}$ & Structural \\
\hline 9 & What is even worse it was time to rob their lives & Structural \\
\hline 10 & Either keep the financial support and then the whole system will collapse & Counter Factual \\
\hline 11 & Or remove the financial support to keep the system intact & Counter Factual \\
\hline 12 & They admit that the financial support has failed so far & Factive \\
\hline 13 & Without providing any solution except for chaos & Factive \\
\hline 14 & They admit that whoever benefited are the rich, monopolists, and & Factive \\
\hline
\end{tabular}




\begin{tabular}{|l|l|l|}
\hline & smugglers. & \\
\hline 15 & It is the government of hysteria & Existential \\
\hline 16 & Her politicians and leaders abused her until death & Lexical \\
\hline
\end{tabular}

Table 5 Appendix B Presupposition (Information Bulletin Introduction 2)

\begin{tabular}{|c|c|c|}
\hline \# & Text & Presupposition Type \\
\hline 1 & After four months of Beirut explosion & Existential \\
\hline 2 & $\begin{array}{l}\text { And after } 40 \text { days of assigning Saed Hariri, the president } \\
\text { designate }\end{array}$ & Existential \\
\hline 2 & And 40 years of existing political powers & Existential \\
\hline 3 & $\begin{array}{l}\text { It seems that the economic, political, and living situations is } \\
\text { deteriorating }\end{array}$ & Factive \\
\hline 4 & While the Lebanese citizen is losing hope & Structural \\
\hline 5 & Even if trying to invoke initiating a government & Counter Factual \\
\hline 6 & $\begin{array}{l}\text { If it has been acknowledged that the current politics is } \\
\text { useless }\end{array}$ & Counter Factual \\
\hline 7 & If they started caring again about people's suffering & Counter Factual \\
\hline 8 & Who are seeking to live a good life & Structural \\
\hline 9 & $\begin{array}{l}\text { Specially that the governor of the bank of Lebanon } \\
\text { informed politicians that this is the last chance to keep on } \\
\text { the financial support of goods }\end{array}$ & Lexical \\
\hline 10 & When it comes to Lebanese journalists migration & Structural \\
\hline 11 & $\begin{array}{l}\text { They discussed issues to support public and private media } \\
\text { organizations }\end{array}$ & Lexical \\
\hline 12 & We will start with the report of the British embassy & Existential \\
\hline 13 & About withdrawing the diplomatic staff & Existential \\
\hline 14 & The British ambassador explained & Lexical \\
\hline 15 & She also explained that & Lexical \\
\hline
\end{tabular}


Table 6 Appendix C Presupposition (Information Bulletin Introduction 3)

\begin{tabular}{|c|c|c|}
\hline$\#$ & Text & Presupposition Type \\
\hline 1 & $\begin{array}{l}\text { The Lebanese follow thousands of news reports and political } \\
\text { programs }\end{array}$ & Factive \\
\hline 2 & They see thousands of striking news & Factive \\
\hline 3 & But they don't take things seriously & Factive \\
\hline 4 & $\begin{array}{l}\text { In regard to the announcement of the majority of politicians, } \\
\text { they either watch it out of fun }\end{array}$ & Structural \\
\hline 5 & Or since it is a status quo & Structural \\
\hline 6 & They speak thousands that people believe to be useless & Factive \\
\hline 7 & The president of Lebanon "Michelle Aoun" & Existential \\
\hline 8 & $\begin{array}{l}\text { in which his presence a normal continuation of his past and } \\
\text { that his only consideration is Lebanon }\end{array}$ & Structural \\
\hline 9 & The Lebanese awakening that always expressed & Factive \\
\hline 10 & $\begin{array}{l}\text { Even if defeated multiple times, if they don't set things } \\
\text { straight, }\end{array}$ & Counter-factual \\
\hline 11 & Away from the useless generalization & Factive \\
\hline 12 & $\begin{array}{l}\text { A needed new judicial uprising against a major recession in } \\
\text { regard to the judicial system }\end{array}$ & Non Factive \\
\hline 13 & $\begin{array}{l}\text { It pushed a lot of people to believe that any issue will be } \\
\text { solved }\end{array}$ & Factive \\
\hline 14 & $\begin{array}{l}\text { Even though they know that coming out of this problem } \\
\text { requires an international acceptance, which will not happen } \\
\text { anytime soon }\end{array}$ & Structural \\
\hline 15 & $\begin{array}{l}\text { People are still hopeful and this is the only things they have } \\
\text { in the long run }\end{array}$ & Factive \\
\hline
\end{tabular}


Table 7 Appendix D Presupposition (Information Bulletin Introduction 4)

\begin{tabular}{|c|c|c|}
\hline \# & Text & Presupposition Type \\
\hline 1 & $\begin{array}{l}\text { It is only a curse that can cause this destruction to a country that is } \\
\text { so small as Lebanon }\end{array}$ & Existential \\
\hline 2 & $\begin{array}{l}\text { But this curse is not from extraordinary forces but from its own } \\
\text { citizens who chose the worst of leaders }\end{array}$ & Structural \\
\hline 3 & And from leaders who only abused the system & Structural \\
\hline 4 & $\begin{array}{l}\text { The last message relayed the French president, in the name of the } \\
\text { group to support Lebanon, which was firm but not the last. }\end{array}$ & Factive \\
\hline 5 & $\begin{array}{l}\text { Macaroon who will visit Lebanon before vacations will not only } \\
\text { focus on the French force in the UNIFEl }\end{array}$ & Structural \\
\hline 6 & $\begin{array}{l}\text { But will extend to meet Lebanese officials and politicians in } \mathrm{Al} \\
\text { Mokhtara palace for a third round table }\end{array}$ & Lexical \\
\hline 7 & $\begin{array}{l}\text { If Lebanese officials were able to form a government, then we will } \\
\text { be able to move under the auspices of France to the stabilization } \\
\text { period }\end{array}$ & Counter factual \\
\hline 8 & $\begin{array}{l}\text { Or we remain in facing our differences which will make } \\
\text { Macaroon leave Lebanon suffer its own deadly fate }\end{array}$ & Structural \\
\hline 9 & Political indicators do not show that there is a logical way & Factive \\
\hline 10 & $\begin{array}{l}\text { For the Lebanese parties close to the president and the free } \\
\text { political movement are presupposing to wave the government of } \\
\text { Hassan Diab and at the same time hold him responsible for not } \\
\text { being able to form a government before going back on using } \\
\text { criteria as a pretext }\end{array}$ & Lexcial \\
\hline 11 & $\begin{array}{l}\text { The president in charge insists on his position which supports } \\
\text { the French }\end{array}$ & Lexical and structural \\
\hline 12 & $\begin{array}{l}\text { But the two Shiaa parties, along with Jonblat, are being aloof } \\
\text { either for regional considerations or for private benefit }\end{array}$ & Factive \\
\hline 13 & $\begin{array}{l}\text { There was news initiated by the free political movement about the } \\
\text { possibility of a visit by the president in charge to Baabda }\end{array}$ & Factive \\
\hline 14 & Knowing that this visit would be in vain & Factive \\
\hline 15 & $\begin{array}{l}\text { There are considerations to relieve the financial support or at } \\
\text { least limit it to save the Bank of Lebanon by saving the foreign } \\
\text { currency }\end{array}$ & Existential \\
\hline 16 & $\begin{array}{l}\text { One hour of rain caused to drown Beirut and its north east suburbs } \\
\text { which wasn't able to redeem itself after the explosion }\end{array}$ & Structural \\
\hline 17 & $\begin{array}{l}\text { Even the snow could not hide the bad infrastructure which is quite } \\
\text { similar to the bad selves of the politicians }\end{array}$ & Structural \\
\hline
\end{tabular}




\section{International Conference on Social Sciences, Humanities and Arts}

Table 8 Appendix E Presupposition (Information Bulletin Introduction 5)

\begin{tabular}{|l|l|l|}
\hline$\#$ & Text & Presupposition Type \\
\hline 1 & $\begin{array}{l}\text { Based on a deputy in the free political party, the president } \\
\text { in charge Saad al Hariri will visit the Baabda castle }\end{array}$ & Existential \\
\hline 2 & $\begin{array}{l}\text { To suggest for the president Aoun the shape of the new } \\
\text { government after agreeing on names }\end{array}$ & Factive \\
\hline 3 & $\begin{array}{l}\text { And in an official announcement that doesn't reflect this } \\
\text { mentality }\end{array}$ & Structural \\
\hline 4 & $\begin{array}{l}\text { The president of the free political movement held the } \\
\text { president in charge ethically and nationally responsible for } \\
\text { procrastination }\end{array}$ & Existential \\
\hline 5 & $\begin{array}{l}\text { Lashing accusations and baring responsibilities endorses the } \\
\text { fact that the forming a government is yet to be achieved }\end{array}$ & Structural \\
\hline 6 & $\begin{array}{l}\text { And while it is known that president Berry is frustrated } \\
\text { from this procrastination }\end{array}$ & Factive \\
\hline 7 & And emphasizing that the only way is to form a government & Lexical \\
\hline 8 & $\begin{array}{l}\text { These local warnings synchronize with international ones } \\
\text { specially the French }\end{array}$ & Existential \\
\hline 9 & The French words fall on deaf ears & Lexical \\
\hline 10 & $\begin{array}{l}\text { One of the most prominent results is wavering the financial } \\
\text { support to be discussed in a governmental meeting }\end{array}$ & Structural \\
\hline 11 & \begin{tabular}{l} 
Knowing that there are three options only \\
\hline
\end{tabular} & Structural \\
\hline
\end{tabular}

Table 9 Appendix F Presupposition (Information Bulletin Introduction 6)

\begin{tabular}{|l|l|l|}
\hline$\#$ & Text & Presupposition Type \\
\hline 1 & $\begin{array}{l}\text { The Lebanese were not shocked by the floods since this is something } \\
\text { they are used to }\end{array}$ & Lexical \\
\hline 2 & $\begin{array}{l}\text { Accompanied by ministries 'apologies and common excuses } \\
\text { Whack crisis }\end{array}$ & Factive \\
\hline 3 & $\begin{array}{l}\text { What is shocking is the white view that is ruined by the recurrent } \\
\text { blactural }\end{array}$ \\
\hline
\end{tabular}




\section{International Conference on Social Sciences, Humanities and Arts}

\begin{tabular}{|c|c|c|}
\hline 4 & $\begin{array}{l}\text { While there are experts for the weather forecast, no expert can } \\
\text { understand the political, economic, or social Lebanese phenomena. }\end{array}$ & Structural \\
\hline 5 & $\begin{array}{l}\text { These crisis were able to remain still until it was affected by an } \\
\text { American involvement controlling Lebanon }\end{array}$ & Factive \\
\hline 6 & $\begin{array}{l}\text { Any economic news is bounded to the governor of the Bank of Lebanon } \\
\text { and his batch of politicians, economics, and journalists who support him }\end{array}$ & Structural \\
\hline 7 & $\begin{array}{l}\text { None of the bank depositors nor the parents of students abroad are able to } \\
\text { break this system of corruption }\end{array}$ & Existential \\
\hline 8 & That controls their kids 'future & Structural \\
\hline 9 & Local and military files are being questioned by courts & Factive \\
\hline 10 & $\begin{array}{l}\text { After the convictions of the internal security forces and the current } \\
\text { investigation of the Lebanese army }\end{array}$ & Existential \\
\hline 11 & $\begin{array}{l}\text { Abbas Ibrahim said: revealing this operation is an honor for the internal } \\
\text { Lebanese security forces }\end{array}$ & Factive \\
\hline 12 & $\begin{array}{l}\text { In regard to Covid }-19 \text {, the Lebanese people only hope is the vaccine } \\
\text { which won't be available in Lebanon before months. }\end{array}$ & Factive \\
\hline 13 & Abiding by the medical measures is a must & Existential \\
\hline 14 & $\begin{array}{l}\text { In addition to the world health's organization warning that coming up } \\
\text { with a vaccine doesn't mean that the pandemic is over. }\end{array}$ & Structural \\
\hline 15 & What is even worse the political and trade markets & Structural \\
\hline 16 & Which will offer the vaccine to some countries rather than the others & Structural \\
\hline 17 & $\begin{array}{l}\text { Which is considered discrimination according to Mohammad Jawad } \\
\text { Tharef, the Iranian foreign minister }\end{array}$ & Structural \\
\hline 18 & $\begin{array}{l}\text { Commenting on the news that Germany is intending to include Israel in } \\
\text { the vaccination European program against covid-19 while excluding the } \\
\text { Palestinians }\end{array}$ & Lexical and Structural \\
\hline 19 & $\begin{array}{l}\text { In Palestine, the Israeli terrorism did not exclude young Palestinians who } \\
\text { commemorated the death of the martyr Ali Abou Alia, a } 14 \text { years old, } \\
\text { who passed away due to gunshots in Al maghir village near Ram Allah }\end{array}$ & Structural \\
\hline
\end{tabular}

Table 10 Appendix G Presupposition (Information Bulletin Introduction 7)

\begin{tabular}{|l|l|l|}
\hline$\#$ & Text & Presupposition Type \\
\hline 1 & Beirut was covered in white despite all the black surrounding it & Existential \\
\hline 2 & $\begin{array}{l}\text { The Lebanese do not expect a good social political exist since the } \\
\text { political parties are suffocating this country }\end{array}$ & Factive \\
\hline 3 & $\begin{array}{l}\text { Being a whiner, the Free Political party held Saad Al Hariri and the } \\
\text { political parliament the responsibility of procrastinating in forming the } \\
\text { government. }\end{array}$ & Factive \\
\hline
\end{tabular}




\section{International Conference on Social Sciences, Humanities and Arts}

\begin{tabular}{|c|c|c|}
\hline 4 & $\begin{array}{l}\text { Refusing the fact that this is done due to current circumstances and given } \\
\text { pressures }\end{array}$ & Structural \\
\hline 5 & $\begin{array}{l}\text { Believing that abiding by fixed criteria and principles is the only way out } \\
\text { for the president in charge }\end{array}$ & Lexical \\
\hline 6 & $\begin{array}{l}\text { Who is the only issue behind forming the government (It's either me or } \\
\text { there won't be Saad al Hariri) }\end{array}$ & Structural \\
\hline 7 & Supporting Gibran is on alert in Baabda & Existential \\
\hline 8 & $\begin{array}{l}\text { Which is obvious in every meeting between the president Michel Aoun } \\
\text { and the president in charge }\end{array}$ & Structural \\
\hline 9 & The president's condition is the one third (Deactivating) & Existential \\
\hline 10 & Even if the country was doomed to hell & Counter Factual \\
\hline 11 & This is the current political situation that the president cannot deny & Structural \\
\hline 12 & $\begin{array}{l}\text { Since he believes that this is the last fight and accordingly he will decide } \\
\text { on his successor }\end{array}$ & Structural \\
\hline 13 & If Gibran Bassil is guilty in the eyes of the American cabinet & Counter factual \\
\hline 14 & Then we will reveal all the skeletons in your closets & Existential \\
\hline 15 & As if corruption is new and now we are considering its results & Counter factual \\
\hline 16 & It is the same corruption with the same three corruptive names & Factive \\
\hline 17 & Which should have been closed already & Structural \\
\hline 18 & $\begin{array}{l}\text { Even though these names should not be defended and are liable to } \\
\text { suspicion }\end{array}$ & Non factive \\
\hline 19 & The main concern is using corruption issue as pretext for war & Factive \\
\hline 20 & The immolation wars will continue & Existential \\
\hline 21 & By calling to empower the government of Hassan Diab & Factive \\
\hline 22 & $\begin{array}{l}\text { This is to force Saad Al Hariri to apologize from being able to form a } \\
\text { government }\end{array}$ & Factive \\
\hline 23 & $\begin{array}{l}\text { A supreme defense council which is only concerned with sewage and } \\
\text { cleaning up }\end{array}$ & Structural \\
\hline
\end{tabular}

Table 11 Appendix H Modality IBI1

\begin{tabular}{|l|l|l|}
\hline$\#$ & Text & Modality Type \\
\hline 1 & Why would the government set such a plan? & Epistemic \\
\hline 2 & Why would the government set such a plan? & Epistemic \\
\hline 3 & Who will fund this plan? & Epistemic \\
\hline
\end{tabular}




\begin{tabular}{|l|l|l|}
\hline 4 & The same will apply to next week's hearing & Epistemic \\
\hline 5 & When the council will flee his responsibilities & Epistemic \\
\hline 6 & $\begin{array}{l}\text { Either keep the financial support and then the whole system } \\
\text { will collapse }\end{array}$ & Epistemic \\
\hline
\end{tabular}

Table 12 Appendix I Modality IBI2

\begin{tabular}{|l|l|l|}
\hline$\#$ & Text & Modality Type \\
\hline 1 & We will start with the report of the British embassy & Epistemic \\
\hline 2 & The British ambassador explained & Epistemic \\
\hline 3 & She also explained that & Epistemic \\
\hline 4 & A successor will be announced later & Epistemic \\
\hline
\end{tabular}

Table 13 Appendix J Modality IBI3

\begin{tabular}{|l|l|l|}
\hline$\#$ & Text & Modality Type \\
\hline 1 & $\begin{array}{l}\text { It pushed a lot of people to believe that any issue will be } \\
\text { solved }\end{array}$ & Epistemic \\
\hline 2 & $\begin{array}{l}\text { Even though they know that coming out of this problem } \\
\text { requires an international acceptance, which will not happen } \\
\text { anytime soon }\end{array}$ & Epistemic \\
\hline 3 & That might be right & Epistemic \\
\hline
\end{tabular}

Table 14 Appendix K Modality IBI4

\begin{tabular}{|l|l|l|}
\hline$\#$ & Text & Modality Type \\
\hline 1 & $\begin{array}{l}\text { It is only a curse that can cause this destruction to a country } \\
\text { that is so small as Lebanon }\end{array}$ & Epistemic \\
\hline 3 & $\begin{array}{l}\text { Macaroon who will visit Lebanon before vacations will not } \\
\text { only focus on the French force in the UNIFEl }\end{array}$ & Epistemic \\
\hline 4 & $\begin{array}{l}\text { But will extend to meet Lebanese officials and politicians in } \\
\text { Al Mokhtara palace for a third round table }\end{array}$ & Epistemic \\
\hline
\end{tabular}




\section{International Conference on Social Sciences, Humanities and Arts}

\begin{tabular}{|c|c|c|}
\hline 5 & $\begin{array}{l}\text { If Lebanese officials were able to form a government, then } \\
\text { we will be able to move under the auspices of France to the } \\
\text { stabilization period }\end{array}$ & Epistemic \\
\hline 6 & $\begin{array}{l}\text { Or we remain in facing our differences which will make } \\
\text { Macaroon leave Lebanon suffer its own deadly fate }\end{array}$ & Epistemic \\
\hline 7 & Knowing that this visit would be in vain & Epistemic \\
\hline 8 & $\begin{array}{l}\text { One hour of rain caused to drown Beirut and its north east } \\
\text { suburbs which wasn't able to redeem itself after the } \\
\text { explosion }\end{array}$ & Epistemic \\
\hline 9 & $\begin{array}{l}\text { Even the snow could not hide the bad infrastructure which } \\
\text { is quite similar to the bad selves of the politicians }\end{array}$ & Epistemic \\
\hline
\end{tabular}

Table 15 Appendix L Modality IBI5

\begin{tabular}{|l|l|l|}
\hline$\#$ & Text & Modality Type \\
\hline 1 & $\begin{array}{l}\text { Based on a deputy in the free political party, the president in } \\
\text { charge Saad al Hariri will visit the Baabda castle }\end{array}$ & Epistemic \\
\hline 2 & Your country will be doomed & Epistemic \\
\hline 3 & The financial support that will be discussed & Epistemic \\
\hline
\end{tabular}

Table 16 Appendix M Modality IBI6

\begin{tabular}{|l|l|l|}
\hline$\#$ & Text & Modality Type \\
\hline 1 & $\begin{array}{l}\text { While there are experts for the weather forecast, no expert } \\
\text { can understand the political, economic, or social Lebanese } \\
\text { phenomena. }\end{array}$ & Epistemic \\
\hline 2 & $\begin{array}{l}\text { These crisis were able to remain still until it was affected by } \\
\text { an American involvement controlling Lebanon }\end{array}$ & Epistemic \\
\hline 3 & $\begin{array}{l}\text { None of the bank depositors nor the parents of students } \\
\text { abroad are able to break this system of corruption }\end{array}$ & Epistemic \\
\hline 4 & $\begin{array}{l}\text { In regard to Covid - 19, the Lebanese people only hope is } \\
\text { the vaccine which won't be available in Lebanon before } \\
\text { months. }\end{array}$ & Epistemic \\
\hline
\end{tabular}




\section{International Conference on Social Sciences, Humanities and Arts}

\begin{tabular}{|l|l|l|}
\hline 5 & Abiding by the medical measures is a must & Deontic \\
\hline 6 & $\begin{array}{l}\text { Which will offer the vaccine to some countries rather than } \\
\text { the others }\end{array}$ & Epistemic \\
\hline 7 & $\begin{array}{l}\text { Which is considered discrimination according to } \\
\text { Mohammad Jawad Tharef, the Iranian foreign minister }\end{array}$ & Epistemic \\
\hline
\end{tabular}

Table 17 Appendix N Modality IBI7

\begin{tabular}{|l|l|l|}
\hline$\#$ & Text & Modality Type \\
\hline 1 & $\begin{array}{l}\text { Who is the only issue behind forming the government (It's } \\
\text { either me or there won't be Saad al Hariri) }\end{array}$ & Epistemic \\
\hline 2 & $\begin{array}{l}\text { Since he believes that this is the last fight and accordingly } \\
\text { he will decide on his successor }\end{array}$ & Epistemic \\
\hline 3 & Then we will reveal all the skeletons in your closets & Epistemic \\
\hline 4 & Which should have been closed already & Epistemic \\
\hline 5 & $\begin{array}{l}\text { Even though these names should not be defended and are } \\
\text { liable to suspicion }\end{array}$ & Epistemic \\
\hline 6 & $\begin{array}{l}\text { The immolation wars will continue } \\
\text { This is to force Saad Al Hariri to apologize from being able } \\
\text { to form a government }\end{array}$ & Epistemic \\
\hline
\end{tabular}

Table 18 Appendix $O$ Deixis

\begin{tabular}{|l|l|l|l|}
\hline$\#$ & Text & IBI \# & Type \\
\hline 1 & When the council will flee his responsibilities & 1 & Personal \\
\hline 2 & Who will fund this plan? & 1 & Spatial \\
\hline 3 & As long as there is no clear answer to this point & 1 & Spatial \\
\hline 4 & The same will apply to next week's hearing & 1 & Temporal \\
\hline 5 & $\begin{array}{l}\text { After the Lebanese people have been robbed, it was time to make } \\
\text { them face hunger. }\end{array}$ & 1 & Temporal \\
\hline 6 & & 1 & Personal \\
\hline 7 & $\begin{array}{l}\text { They admit that whoever benefited are the rich, monopolists, and } \\
\text { smugglers. }\end{array}$ & 1 & Personal \\
\hline
\end{tabular}




\section{International Conference on Social Sciences, Humanities and Arts}

\begin{tabular}{|c|c|c|c|}
\hline 8 & Its politicians and leaders abused it until death & 1 & Personal \\
\hline 9 & If they started caring again about people's suffering & 2 & Personal \\
\hline 10 & Who are seeking to live a good life & 2 & Personal \\
\hline 11 & $\begin{array}{l}\text { Specially that the governor of the bank of Lebanon informed } \\
\text { politicians that this is the last chance to keep on the financial } \\
\text { support of goods }\end{array}$ & 2 & Spatial \\
\hline 12 & $\begin{array}{l}\text { They discussed issues to support public and private media } \\
\text { organizations }\end{array}$ & 2 & Personal \\
\hline 13 & We will start with the report of the British embassy & 2 & Personal \\
\hline 14 & She also explained that & 2 & Personal \\
\hline 15 & They see thousands of striking news & 3 & Personal \\
\hline 16 & But they don't take things seriously & 3 & Personal \\
\hline 17 & Or since it is a status quo & 3 & Personal \\
\hline 18 & They speak thousands that people believe to be useless & 3 & Personal \\
\hline 19 & $\begin{array}{l}\text { in which his presence a normal continuation of his past and that his } \\
\text { only consideration is Lebanon }\end{array}$ & 3 & Personal \\
\hline 20 & The Lebanese awakening that always expressed & 3 & Temporal \\
\hline 21 & Even if defeated multiple times, if they don't set things straight, & 3 & Personal \\
\hline 22 & $\begin{array}{l}\text { Even though they know that coming out of this problem requires an } \\
\text { international acceptance, which will not happen anytime soon }\end{array}$ & 3 & $\begin{array}{l}\text { Personal and } \\
\text { Temporal }\end{array}$ \\
\hline 23 & $\begin{array}{l}\text { The last message relayed the French president, in the name of the } \\
\text { group to support Lebanon, which was firm but not the last. }\end{array}$ & 4 & Temporal \\
\hline 24 & $\begin{array}{l}\text { If Lebanese officials were able to form a government, then we will } \\
\text { be able to move under the auspices of France to the stabilization } \\
\text { period }\end{array}$ & 4 & Personal \\
\hline 25 & $\begin{array}{l}\text { Or we remain in facing our differences which will make Macaroon } \\
\text { leave Lebanon suffer its own deadly fate }\end{array}$ & 4 & Personal \\
\hline 26 & $\begin{array}{l}\text { For the Lebanese parties close to the president and the free political } \\
\text { movement are presupposing to wave the government of Hassan } \\
\text { Diab and at the same time hold him responsible for not being able } \\
\text { to form a government before going back on using criteria as a } \\
\text { pretext }\end{array}$ & 4 & $\begin{array}{l}\text { Personal and } \\
\text { Temporal }\end{array}$ \\
\hline 27 & $\begin{array}{l}\text { The president in charge insists on his position which supports the } \\
\text { French }\end{array}$ & 4 & Personal \\
\hline 28 & Knowing that this visit would be in vain & 4 & Spatial \\
\hline
\end{tabular}




\begin{tabular}{|c|c|c|c|}
\hline 29 & $\begin{array}{l}\text { One hour of rain caused to drown Beirut and its north east suburbs } \\
\text { which wasn't able to redeem itself after the explosion }\end{array}$ & 4 & Temporal \\
\hline 30 & $\begin{array}{l}\text { To suggest for the president Aoun the shape of the new government } \\
\text { after agreeing on names }\end{array}$ & 5 & Temporal \\
\hline 31 & And in an official announcement that doesn't reflect this mentality & 5 & Spatial \\
\hline 32 & $\begin{array}{l}\text { Lashing accusations and baring responsibilities endorses the fact } \\
\text { that the forming a government is yet to be achieved }\end{array}$ & 5 & Temporal \\
\hline 33 & $\begin{array}{l}\text { And while it is known that president Berry is frustrated from this } \\
\text { procrastination }\end{array}$ & 5 & Spatial \\
\hline 34 & $\begin{array}{l}\text { These local warnings synchronize with international ones specially } \\
\text { the French }\end{array}$ & 5 & Spatial \\
\hline 35 & $\begin{array}{l}\text { The Lebanese were not shocked by the floods since this is } \\
\text { something they are used to }\end{array}$ & 6 & Spatial \\
\hline 36 & $\begin{array}{l}\text { These crisis were able to remain still until it was affected by an } \\
\text { American involvement controlling Lebanon }\end{array}$ & 6 & Spatial \\
\hline 37 & $\begin{array}{l}\text { Any economic news is bounded to the governor of the Bank of } \\
\text { Lebanon and his batch of politicians, economics, and journalists } \\
\text { who support him }\end{array}$ & 6 & Personal \\
\hline 38 & $\begin{array}{l}\text { None of the bank depositors nor the parents of students abroad are } \\
\text { able to break this system of corruption }\end{array}$ & 6 & Spatial \\
\hline 39 & That controls their kids 'future & 6 & Personal \\
\hline 40 & $\begin{array}{l}\text { After the convictions of the internal security forces and the current } \\
\text { investigation of the Lebanese army }\end{array}$ & 6 & Temporal \\
\hline 41 & $\begin{array}{l}\text { Abbas Ibrahim said: revealing this operation is an honor for the } \\
\text { internal Lebanese security forces }\end{array}$ & 6 & Spatial \\
\hline 42 & $\begin{array}{l}\text { In regard to Covid }-19 \text {, the Lebanese people only hope is the } \\
\text { vaccine which won't be available in Lebanon before months. }\end{array}$ & 6 & Temporal \\
\hline 43 & $\begin{array}{l}\text { The Lebanese do not expect a good social political exist since the } \\
\text { political parties are suffocating this country }\end{array}$ & 7 & Spatial \\
\hline 44 & $\begin{array}{l}\text { Refusing the fact that this is done due to current circumstances and } \\
\text { given pressures }\end{array}$ & 7 & Spatial \\
\hline 45 & $\begin{array}{l}\text { Who is the only issue behind forming the government (It's either } \\
\text { me or there won't be Saad al Hariri) }\end{array}$ & 7 & Personal \\
\hline 46 & This is the current political situation that the president cannot deny & 7 & Spatial \\
\hline 47 & $\begin{array}{l}\text { Since he believes that this is the last fight and accordingly he will } \\
\text { decide on his successor }\end{array}$ & 7 & $\begin{array}{l}\text { Spatial and } \\
\text { Personal }\end{array}$ \\
\hline 48 & Then we will reveal all the skeletons in your closets & 7 & Temporal \\
\hline
\end{tabular}




\begin{tabular}{|l|l|l|l|}
\hline & As if corruption is new and now we are considering its results & 7 & and personal \\
\hline 49 & $\begin{array}{l}\text { Temporal } \\
\text { and personal }\end{array}$ \\
\hline 50 & $\begin{array}{l}\text { Even though these names should not be defended and are liable to } \\
\text { suspicion }\end{array}$ & 7 & Personal \\
\hline 51 & $\begin{array}{l}\text { This is to force Saad Al Hariri to apologize from being able to form } \\
\text { a government }\end{array}$ & 7 & Spatial \\
\hline
\end{tabular}

